\title{
Language, Entanglement and the New Silk Roads
}

K.M. Fierke and Francisco Alfonso-Antonio

The authors would like to thank Lily Ling, Chaeyoung Yong and the reviewers for comments on this text, as well as the Netherlands Institute for Advanced Studies, where K.M. Fierke was a fellow in the final stages of completing this article. 
Observers have tended to place the Silk Road proposals in the context of 'China's rise,' and its increasing influence and interests in Central, South and South-East Asia. From a realist perspective, China, like any expanding state, poses a potential threat. From a liberal angle, it is expanding the space for cooperation. Both models rely on an individualist ontology that highlights the interests of individual states. The potential of the Silk Roads looks somewhat different if approached from the perspective of a more relational ontology and a concept of entanglement. We draw on a few claims from Alexander Wendt's (2015) recent book as a framework for examining the emerging reality of the new 'Silk Roads.' What are the implications of this ontological shift for thinking about the Chinese 'Silk Road' proposal, and is this metaphor or reality? We develop three specific claims as part of a reflection on this context: first, language use is a form of measurement that shapes and transforms reality; second, language use is an expression of entanglement; and third, leaders have a large role in 'collapsing wave functions' around specific potentials. While some of the themes that arise in this discussion are compatible with other arguments about the role of language, the quantum angle provides a more explicit point of departure for discussing the 'physical' dimensions of language use, the multiple layers of meaning within which the OBOR is embedded and its relational ontology. 
On 7 September 2013, at Nazarbayev University in Astana, Kazakhstan, Chinese president Xi Jinping 'proposed to build an 'economic belt along the Silk Road' (China Daily, 2013a). Later, on 2 October, in a speech to the Indonesian Parliament, he announced an effort to build 'the Maritime Silk Road of the 21th century' (China Daily, 2013b). Both projects have since acquired significant political momentum. In May 2014 the city government of Fuzhou signed an agreement with the China Africa Development Bank and the Fujian branch of the China Development Bank to jointly set up a $\$ 1.6$ billion fund for a 'maritime silk road' plan, for the purpose of building ports and to boost maritime connectivity with Southeast Asia and countries along the Indian Ocean (Shanghai Daily, 2014). In November, at the Beijing APEC summit, President Xi announced that China would contribute $\$ 40$ billion to set up the Silk Road fund, which would be used to provide investment and financial support to facilitate infrastructure, industrial and financial cooperation (China.org, 2014). As of January 2015, \$100 billion had been authorized for the Asian Infrastructure Investment Bank (AIIB), which now has 82 members (Weinland, 2017), to supply the capital for infrastructure construction (People's Daily, 2015). What has since been more formally named the 'One Belt, One Road' Initiative (OBOR) will include a free trade zone to link coastal areas, 'infrastructure construction' in countries such as Pakistan, Sri Lanka and Bangladesh (Krishman, 2014), and high-speed rail negotiations with 28 nations, most along the ancient trade routes, with a total length of track over $5000 \mathrm{~km}$ on the agenda.

Observers have tended to place the Silk Road proposals in the context of 'China's rise,' and its increasing influence and interests in Central, South and South-East Asia. Many foreign analysts have referred to the OBOR as 'a comprehensive strategy' or a 'geopolitical and diplomatic offensive' (Pop, 2016). Realists have argued that China intends to use its robust infrastructure programme to create overseas bases to threaten India's perceived sphere of influence and increase Chinese influence by challenging the regional order. For example, Kanwal Sibal (2014) argues that the ultimate goal of the Chinese rhetoric of the Maritime Silk Road is to 'create a strategic space for itself in the western Pacific and then move into the Indian Ocean gradually'. Nicholas (2015) found somewhat stronger evidence to support a liberal argument regarding the opportunities for common development, multilateral growth and addressing the failures of current global and regional institutions. Tiezzi (2014a; 2014b) 
puts a realist spin on the liberal economic perspective, noting that even if China only envisions economic movement as its rationale for building the Silk Roads, these by themselves represent a strategic action, not least because investment can be translated into a 'potential weapon'. From a realist perspective, China, like any expanding state, poses a potential threat. From a liberal angle, it is expanding the space for cooperation. Both models rely on an individualist ontology that highlights the interests of individual states. Neither perspective can shed light on the conceptual challenges that Chinese proposals present for world politics, assuming instead that China either wants to cooperate (the liberal argument) or conquer (the realist argument). Neither can accommodate the possibility that China's rise may not only alter the world's distribution of power, but may also reconfigure the way that global politics work. In so far as both liberalism and realism assume a world 'out there,' fully formed, there is little recognition of the conceptual underpinnings of different world orders. China's new silk roads, as a constitutive element of its rise as a world power, are not only a material phenomenon but part of a conceptual reorganization that will impact on the norms, institutions and the behaviour of diplomacy (Callahan 2016).

The potential of the Silk Roads looks somewhat different if approached from the perspective of a more relational ontology and a concept of entanglement. ${ }^{1}$ Language, as an expression of entanglement, both enables and constrains precisely because of its relationality. While the notion of entanglement and its implication might be unpacked from the perspective of quantum physics, or a Buddhist or Daoist ontology, ${ }^{2}$ given space constraints, we draw on a few claims from Alexander Wendt's book, Quantum Mind and Social Science, which provides a concise, if rather dense, formulation for a social science audience (Wendt, 2015). The book does not address the empirical implications of a relational ontology, or its significance for the political context explored here. What follows is an attempt to grapple with the significance of a small part of his argument as a framework for understanding the emerging reality of the new 'Silk Roads.'

\footnotetext{
${ }^{1}$ The idea that 'reality' is instantiated in language is evident in ancient thinkers, such as Wang Chen, who in the Tao of Peace, identified a human tendency to conceptualize as a source of conflict and suffering in the world (Wang, 1999: 14), or in the $2^{\text {nd }}$ century Buddhist philosopher Nagarjuna's concept of 'dependent origination,' or more recently, the Chinese philosopher Zhao who explores the ancient Chinese concept 下 Tianxia (All-under-heaven), for thinking about contemporary global politics (Zhao, 2009).

${ }^{2}$ Here is worth mentioning the family resemblance, identified by Niels Bohr (1958), between quantum physics and Eastern wisdom. For an examination of this family resemblance as it relates to Wendt's argument, see (Fierke, 2017).
} 
Wendt argues that the social sciences, and the dominant frameworks of International Relations, whether realism, liberalism or constructivism, rely on assumptions of materiality, atomism, mechanism, determinism and objectivism, which have their origins in classical physics. When applied to the Chinese OBOR, this view, as expressed by realists, would see a great power expanding its material and strategic interests, perhaps influenced by a mechanistic balance of power, and a deterministic relationship between capability and success, all of which can be assessed by an outside objective observer. Quantum physics expands the space within which the materiality of classical physics is understood, thereby opening possibilities to resolve otherwise intractable problems. Wendt's approach to the relevance of quantum physics for the social sciences highlights the entanglement of wave functions, language as an expression of entanglement, a holistic universe, the possibility of non-local causation and a norm of indeterminism, all of which provides a physical basis for mutual constitution that is otherwise untenable (Wendt, 2015).

What are the implications of this ontological shift for thinking about the Chinese 'Silk Road' proposal, and is this metaphor or reality? While doing justice to his complex argument would be a very large task, in this short piece we develop three claims from the book as part of reflection on a particular context: first, language use is a form of measurement that shapes and transforms reality; second, language use is an expression of entanglement; and third, while leaders have a large role in 'collapsing wave functions' around specific potentials, the realisation of these potentials is fundamentally dependent on practice on the ground. While some of the themes that arise in this discussion are compatible with other arguments about the role of language, the quantum angle provides a more explicit point of departure for discussing the 'physical' dimensions of language use.

\section{Language use is a form of measurement}

While Xi Jinping's reference to the ancient 'silk roads' can be understood as either metaphor or analogy, given their link to an historic past, Wendt's quantum argument rests on a claim that language use transforms reality. As he states, 'In language, what brings about a concept's collapse from potential meaning into an actual one is a speech act, which may be seen as a measurement that puts it into a context, with both words and potential listeners' (Wendt, 2015: 217). This claim about measurement builds on the famous double slit experiment in quantum physics which established that observation changes the object of 
measurement. ${ }^{3}$ The quantum argument deals in multiple potentials and the collapse of wave functions around one potential rather than others (Wendt, 2015). So, while China is a nationstate, and a participant in the practices of interstate-diplomacy, the Silk Roads, as a speech act, instantiates a different measure of reality. This measure provides the actors involved with a specific set of identities and intentions, establishes a specific narrative of time and sets up a particular line of historical development, a complex mix of reality which realism and liberalism are not theoretically equipped to tackle.

Chinese leaders state that they are 'reviving' the ancient Silk Road (see Xinhua, 2015), which implies that the contemporary phenomena is the Silk Road rather than analogous to it, although what is being revived differs dramatically from the original, given the role of modern infrastructure and the trade of oil. The more recent history of international relations has been framed around states with clear boundaries that distinguish 'us' and 'them,' and there is a strong pull to re-enact this potential. ${ }^{4}$ Having said this, Asian states have historically been victim to the expansion of modern statehood, as reflected not least in China's 'century of humiliation.' 5

The Silk Roads arise from a much older historical memory that is very much alive in Asia, although this broader view of history has elsewhere been all but forgotten or orientalised (Frankopan, 2015). While China had an important place along the ancient Silk Roads, they had no single centre. The spatial construction of roads covered an expansive area, spanning Eurasia and including the seas. The Silk Roads were characterised less by states fixed in space than process, movement and exchange, although also dependent on local powers to maintain the security of the routes. The latter suggests a world constituted around multiple perspectives, where knowledge was not imposed from a single Archimedian point, but arose from engagement across multiple locations in space.

\footnotetext{
${ }^{3}$ According to Robin Wang, from a Daoist perspective, that anything can be simultaneously yin or yang reinforces the fact that 'things are always implicated in multiple relations at once.' It is the intentions and priorities of the observer that determine which relation is in view (Wang, 2012: 7). This conclusion resonates with the outcome of the double-slit experiment in quantum physics that measurement changes the object of observation.

${ }^{4}$ Indeed, the OBOR has been presented as analogous to Europe between the end of the $19^{\text {th }}$ century and the years before World War I, when 'strong nations jostled one another for industrial and military dominance. In this argument, the OBOR strategy combines land power and maritime power, bolstering China's existing oceanic hegemony in East Asia. See (Tsui et al, 2017).

${ }^{5}$ The "Century of Humiliation" refers to a period between 1839 and 1949 of imperialism by Western powers and Japan in China. See, for instance, Wang 2014.
} 
In so far as Chinese proposals refer to future potentials, the speech act provides the broad contours of what is to be constructed, and a particular measurement of what would otherwise be a series of land tracks and sea routes, with people bumping into each other along the way. In this respect, it establishes a context in a situation that would otherwise lack clear structure or boundaries. This framework then guides - although it does not entirely determine - how actors understand themselves within it and thus what they do. The 'Silk Road' evokes a set of meanings and possibilities. The metaphor of Silk, for example, suggests that items of very high quality and value are being traded. The road alludes to a place of travel that connects one place to another. Furthermore, although the US, India and China share an interest in having a key economic and political role in Asia, only China frames its interests as a continuation of an order that extends over a very long timespan in which Chinese leadership was the rule and its weakness the brief exception. All this helps to clarify that, by definition, for China the new Silk Roads are long-term tools to shape the world both conceptually and materially, rather than a short-term strategy to achieve global hegemony, as is so often assumed (see Yale, 2015).

Social scientific methodology presumes the ability to analyse an objective material world independent of the meaning human agents bring to it. Measurement involves the enumeration of causal relations between subjects or objects that are assumed to have an intrinsic identity. By contrast, the naming of the Silk Road, from a more quantum perspective, contains a measurement in and of itself. This instantiates a material reality that will further unfold, not least because the concept has become a focal point for multilateral agreements regarding investments and development within this context. To say that it is a work in progress is to point both to the renaming of a range of practices and material developments, many of them well established (India's World, 2014), as well as a shift in the meaning of those practices, and how various participants engage with each other. At the core is the difference between understanding units as ontologically apriori and separate, as in realism and liberalism, as opposed understanding identity as emergent, in the case of the Silk Roads. A further distinction can be made between the measure of 'what is' in social scientific methodology in contrast to quantum measurement in which observation transforms its object.

The 'Silk Roads,' as presented by the Chinese leadership, contain a measurement of a regional or global reality which establishes a particular vision with practical import; its symbolism is one of cultures interacting, learning from one another, and the exchange of goods and ideas. In discussing the new Silk Roads, President Xi Jinping and other Chinese 
leaders point to a strategy of connectivity and relationality, which rests on an acceptance of diversity, respecting each other's core interests and concerns. ${ }^{6}$ The fear is that Chinese 'order' will eliminate diversity - and here critics might point to the quelling of dissent in China or the repression of Tibet. The conception of order implied by 'All under Heaven,' as articulated by the Chinese philosopher Zhao Tingyang, or the Silk Roads, as articulated by Chinese leaders, suggests that it is possible for order (harmony) and diversity to co-exist, and the Silk Roads provide an historical precedent (Callahan, 2008: 751-52).

The OBOR strategy has five major goals within a broad framework of connectivity and cooperation, which includes policy coordination; facilitating connectivity; unimpeded trade; financial integration and people-to-people bonds (NDRC, 2015). The core is a stated intention to build peaceful and mutually beneficial cooperation, two ideas that have been part of China's international agenda. The conceptualization of the Silk Roads is closely linked to what has been defined as a “spirit” (精神, jīngshén) of peace (和平, hépíng), friendship (友好 , yǒuhăo), openness (开放 kāifàng) and inclusivity (包容, bāoróng). ${ }^{7}$ The 'Silk Road Spirit' includes 'peace and cooperation, openness and inclusivity, mutual learning and mutual benefit' (NDRC, 2015), which should prevail throughout the new Silk Road, as was the case in the past. In China's view, ancient trade and cultural interchange along the Silk Road was peaceful, as represented for instance, by the migration of Buddhism from India to China, cross-cultural exchanges across the region, and the spread of art, all of which suggest that today's cultural exchange will once again be an important element of the OBOR (Xinhuanet, 2014b; 2014c). As stated by Xi Jinping at the Boao Forum for Asia Annual Conference in 2015, 'the Belt and Road' will 'promote inter-civilizational exchanges to build bridges of friendship for our people, drive human development and safeguard peace in the world. ${ }^{8}$ In brief, the Chinese proposals form part of a more comprehensive approach to regional or global politics that highlights the peaceful character of China's foreign affairs. Chinese leaders themselves have linked the proposal to the Five Principles of Peaceful Coexistence which underpin the foreign policy of People's Republic of China (Xi, 2014).

\footnotetext{
${ }^{6}$ See, for instance, (Yang, 2014), (Pu et al, 2014) and (Chen and Tang, 2014)

${ }^{7}$ The arrangement of the components and the terms employed differ slightly in the sources, but most of them in both Chinese and English point out to the same positive characteristics of the Chinese policies. This particular one is from Chinese Foreign Minister Wang Yi (NPC, 2014); see also (Xinhuanet, 2014a).

${ }^{8}$ As cited in (Winter, 2016).
} 
China's proposals emphasize repeatedly the important role of mutuality and mutual respect in its international conduct. Chinese texts signal, in diverse ways, a call to integrate its own interests with the development of other countries. The Chinese government has frequently stated that the project should be mutually constructed by all parties involved in both its conceptualisation and implementation (People's Daily, 2014). As with the peaceful approach mentioned above, concepts such as mutual benefit, win-win or mutual construction (互利 hùlì, 共赢 gòngyíng and 共建 gòngjiàn respectively), are consistent with previous Chinese foreign policy discourse. ${ }^{9}$ Thus far China has managed to balance its ambitions with a largely peaceful and cooperative foreign policy, as defined by its own discourse. This grants legitimacy to the new Silk Roads, although there is no question that the sheer scale of China's objectives raises questions about its intentions, i.e. regional/global hegemony (Dobra-Manço, 2015). However, while realism can only conceive of a world in which China seeks power for the sake of power, a quantum reading of intentionality is about potentials, and in this case China's potential to become an hegemonic power while building a global order based of mutual gains and peaceful coexistence.

\section{Language and Entanglement}

Realists are concerned that the language of politicians can't always be trusted, in so far as it may disguise intentions other than those communicated in language, which rests on an assumption that language is epiphenomonal to material reality. A clear example can be found in E.H. Carr's (2016) classical work on liberal language of 'Harmony of Interests' in the period of crisis between World Wars I and II. One of Wendt's key claims is that consciousness and intention, while often ignored in social sciences, have not been adequately addressed. The 'hard problem' is that one can't get to a notion of consciousness from a purely materialist perspective. ${ }^{10}$ He situates consciousness at the interface between inside and outside, highlighting its subjective or private dimensions as well as its relational qualities. Organisms - and he does not distinguish human organisms from other forms of life, 'all the

\footnotetext{
${ }^{9}$ Official Chinese discourse depicts China's development as a process that is diametrically opposed to the rise of European/American imperialism, which is in turn depicted as a historical anomoly that interrupted the peaceful way of conducting international affairs that is said to characterize China for hundreds of years. Both Mao Zedong and Deng Xiaoping made of this a quintessential component of their ideological projects.

${ }^{10}$ From a realist perspective, intention is difficult to access given the 'other minds' problem. $\mathrm{He}$ further argues that those who highlight the intersubjective dimensions of language, do not sufficiently acknowledge human subjectivity and the more private dimensions of consciousness.
} 
way down' - have a sense of 'I' or 'what it is like' to be them (Wendt, 2015: 142), but also depend on energy from the environment to survive. Against this backdrop, Chinese President $\mathrm{Xi}$ Jinping's statement in response to the economic policies of the new Trump administration in the U.S. are of interest: 'Pursuing protectionism is like locking oneself in a dark room. While wind and rain may be kept outside, that dark room will also block light and air' (Phillips, 2017). Whether at the level of cells, individual or states, it is less a hard wall than a permeable membrane that distinguishes inside from outside.

This then raises the question of how to understand the Chinese intention in constituting the OBOR. From the realist perspective, we have every reason to be suspicious of Chinese activities, given that it has demonstrated its muscle in the East or South China Seas and its economic investments along the Silk Road will give it undue leverage over more local policies. As a great power with regional and global interests, the expansion of its power is undoubtedly an element of 'its' intention. The point of Wendt's argument is that the wave function collapse of individuals, while instantiated through their practices, is also entangled in social structures and cannot be fully separated from more collective intentions that make them possible (Wendt, 2015: 264-5). ${ }^{11}$ The language of the Silk Roads is constitutive of a particular reality which is prior to any truth claims. As such intention is not merely the sum of individuals as separate parts, but holistic and constituted through non-local entanglements mediated by language. The potentials expressed by the 'Silk Roads,' and their material instantiation do not belong solely to Xi Jinping nor even, in so far as this potential covers a large space covering the Eurasian continent, China alone. It is dependent on practices on ground, across this huge expanse of territory and water, including the degree to which other societies and states buy into them and themselves articulate or contest this potential through their practices. Wang Yiwei (2017) captures the point in his examination of the Chinese meaning of 'road' as 'way,' which is also a reference to the Dao. In the Chinese character Daolu, which means 'road,' Lu is the method to realize the Dao, which today means 'the community facing the same fate. ${ }^{, 12}$ He thus highlights the extent to which the openness of the

\footnotetext{
${ }^{11}$ As Callahan (2016: 229) notes, the breadth and depth of Chinese diplomacy has expanded dramatically in recent decades. He highlights the argument of Shambaugh (2013: 45-120) that Chinese policymaking has to be understood in terms of five nested rings of actors, starting with senior decisionmaking leaders and fanning out from ministries to intelligence organism, localities and corporations and finally to society. Given the multiplicity of actors involved, one can raise of question of whose intention?

${ }^{12}$ This follows a reference to Chapter 42 of the Dao de Ching, the ancient classic of Daoism.'Dao generates one, one generates two, two generates three and then three generates our world.
} 
Belt and Road to all players, and its inclusivity as opposed exclusivity, is embedded in the language itself.

To focus purely on Xi Jinping's intentionality, as an individual leader, is to ignore the further layers of intentionality within which he is embedded from the intersubjective environment of the Chinese leadership to the populations and authorities at various points along the Silk Roads to those outside, such as the United States. The key point about entanglement is that what is going on 'inside the mind' cannot be separated entirely from the language by which Xi Jinping or other Chinese leaders engage with their environment. This is not a causal relationship of imposing inside 'will' on the outside world, but a dynamic relationship between mutually interdependent parts, which is at the heart of Wendt's claim that quantum physics provides a physical basis for mutual constitution that is otherwise untenable. A concept of entanglement highlights the extent to which intention, precisely because it is expressed in language, relies on layers of meaning, some of which are more specific to Chinese culture. For example, some authors have argued that China's relations with other nations are influenced by the traditional ideal of not only being a powerful actor but also to be seen as a morally perfected one. The idea is rooted in Confucianism, for which obedience to the authority is not derived from coercion but from a leader's virtue (Harrell, 2013). When translated into the international dynamics of the OBOR, this means that Chinese leaders may well understand the proposal to be a mere component of a greater strategy to make China the next global hegemon, as realists would expect; however, their presentation of the OBOR as a project that will provide mutual benefits for its participants and peaceful cooperation for the world, points to an order that will, in their view, be morally superior to what exits today. which echoes the aforementioned Confucian premise, regarding the superiority of virtue over force.

\section{Leaders are important}

Wendt's book concludes with a discussion about the role of leaders in collapsing wave functions around specific potentials, and thus the importance of bringing leaders back into the frame. He points, for instance to the difference that the election of President G.W. Bush, as opposed to $\mathrm{Al}$ Gore, made to the shape of international relations. Leaders, who have authority to speak for the state as a whole collapse a states' potentialities into an actual choice with non-local consequences for everyone else in the group, and thus their intentions and character are important (Wendt, 2015: 260), a claim that resonates with Confucian arguments 
about the importance of wise leaders. But a focus on leaders obscures the extent to which the potentialities they express are framed in larger public discourse and dependent on practice on the ground for their realization. Indeed, the UK Brexit vote or Trump's election in the U.S. arose from a groundswell that represented in part a rejection of established leaders, even while constituting a space for the emergence of new ones. In the case of Xi Jinping's Silk Road speech act, contestation from those potentially affected has been as apparent as agreement and participation in the OBOR. While Wendt emphasizes that social structures are 'continuously popping in and out of existence with the practices through which they are instantiated,' the role of contestation - and indeed politics more generally - is largely missing from his argument. This is particularly evident in his claim that that the actualization of social structures and identity expresses a teleological purpose, which points towards its realization (Wendt, 2015: 265).

But what happens when the 'teleological purpose' of one leader's instantiation comes into conflict with another? Take, for instance, the dispute over the Senakaku/Diaoyu islands, which arose from 'wave function collapse' around and the distinct teleological purposes of two potentials, i.e. Japanese and Chinese. The islands themselves are material, and there are interests relating to oil, but the dispute itself is primarily conceptual. Contrary to the claim of one American writer that these islands 'appear from afar to be a jumble of meaningless rocks' (French, 2014), the conflict revolves around the naming of the islands, when they were occupied, the distinction between inhabited and occupied, different versions of international law, i.e. historically imposed by the West, in the view of the Chinese, or 'imposing an arbitrary or at least an un-Western and unfamiliar logic,' in the view of Japan (Lee, 2011). There is no purely objective basis for determining the 'truth' of any of these claims, beyond the social language by which they have been defined and contested. Or consider the now defunct Trans-Pacific Partnership (TPP), which provided a framework for regional relations in Asia that contrasted with the instantiation of the OBOR. These represent two distinct articulations of spatial organization and what these relations should look like, in so far as the former reserved a far larger place for U.S. involvement and influence than the latter.

U.S. President Trump's decision to withdraw from the TPP, has paved the way for the realization of the Chinese plan, not least because Trump's own vision has increased the attractiveness of the former to many who would otherwise be skeptical, given its emphasis on free trade (Phillips, 2017). President Trump is instantiating a reality of hard protectionist walls around the U.S, which includes a measurement of immigrants or refugees, which goes 
against the grain of certain American core values and constitutional guarantees. On the other hand, the new Silk Roads, have aroused suspicion and protest, not least in the context of East Asian island disputes. The removal of the TPP from the equation, shifts the contestation away from the horizontal relationship between the U.S. and China over the framing of Asian regionalization. As already stated, the ancient Silk Roads express a particular meaning and type of regionalization or globalization that differs historically from the nation-state model, even while co-existing with it. Not only does the proposal have a power of appeal and legitimacy, given the meaning attached to the Silk Roads over several centuries of history, but the road, in the form of the OBOR, has already begun to materialize into a new, concrete entity with the construction of institutions, infrastructure, rail networks and ports. Both Trump and Xi Jinping are engaging actively in the process of transforming a relational reality in very different ways. While the one is pulling inward, putting America first, the other is building 'connectivity' across the Eurasian continent. While the contrast and its significance deserve greater attention than is possible here, we want to highlight the ontological differences between the two frameworks against the backdrop of Wendt's argument. While Wendt's claims are purely theoretical and focused on scientific argument rather than any political context, this juxtaposition highlights the danger of the hard walls being built around America, while raising questions about what the entanglement suggested by the Silk Roads might mean, which returns to the question of Chinese intentions.

One of the strengths of the final section of Wendt's book is the much clearer articulation in theoretical terms of the possibility of a social subjectivity. Social subjectivity contributes to a sense of collective identity as a community, not bounded by impermeable boundaries but rather entangled with that which is defined as outside. The organism needs to breathe, and this is dependent on an openness to and entanglement with its larger environment. This is a far better metaphor for intra-global relations, than the frequent conception of realist international relations in terms of, for instance, impenetrable billiard balls. Wendt, drawing on Karen Barad's (2007 : 140) notion of 'intra-action', states that 'who we become through measurements of each other is internal to our relationships - our entanglement - rather than something that happens outside of them' (Wendt, 2015: 172). ${ }^{13}$

\footnotetext{
${ }^{13}$ The notion of intra-national relations builds on Barad's argument that due to uncertainty, the distinction between subjects and/or objectives only becomes evident at the moment of interaction, that is it represents an intra-action by which each is formed by the other rather than engaging from the position of two intrinsic identities. Earlier Edkins (2003) made a similar argument with specific reference to international security, which she argued treats objects as independent of observation and
} 
The concept of intra-action assumes that difference is defined within wholes, which can be distinguished from a realist or liberal perspective, which begins with the separability of individual unit, as in the 'inter-national,' which presumes the ontological separateness of states.

Beginning to conceptualize 'intra-global relations,' and the importance of balance and interdependence between inside and outside, may provide an alternative way to think about globalisation, as Western states begin to collapse inward. The Chinese 'One Road, One Belt', while more open and 'connective', is rightly a concern for many, particularly if the diversity and respect embedded in its instantiation are not matched by practices on the ground. But Barak Obama's point, as he was stepping down as leader, highlights the crucial point that ultimately none of this is about leaders - it is about all of us, normal people. ${ }^{14}$ Leaders are instantiations in and of themselves, so contestation over who they should be and how they should act is important. In so far as one might see some wisdom in Xi Jing's warning against being in a closed room with no air, the main point is not that the world should embrace China rather than the U.S. ${ }^{15}$ Unless China is assumed to be all powerful in its ability to impose its will on the region or the globe, then the 'Silk Road' speech act instantiates a framework of interaction that limits Chinese power, even while empowering it. Language instantiates and is entangled with practice in the world; it does not stand outside it. The extent to which sceptical countries, such as India or Vietnam, can enact diversity, openness and respect, or contest its absence, along the OBOR will have an impact on how the regional networks develop.

The physicist John Wheeler noted that we are all 'participants' in constructing the universe (Folger, 2002). In an uncertain world, the plans of Chinese leaders or any other should not be taken at face value. From this perspective, the OBOR represents neither a straightforward pursuit of global domination, nor should we ignore concerns about China's power vis-à-vis its neighbours. The Silk Roads instantiate particular forms of practice, and not least respect for diversity, multiculturalism and connectivity, upon which the trust and

as existing before they interaction, based on a Newtonian cosmology that arose alongside forms of political community that led to the modern sovereign state (Edkins, 2003).

${ }^{14}$ Although here one might then also point to the 1 in 113 people in the world or are displaced through persecution, war or environmental catastrophe (Edwards, 2016), and who have limited capacity to speak precisely because they are stateless.

${ }^{15}$ Many would see this as dangerous, given China's own record on human rights. It would look particularly ominous, I suspect, from the perspective of a Buddhist in Tibet. 
legitimacy of China will depend. ${ }^{16}$ Just as yin always contains an element of yang (Ling, 2014), China is both a participant in the existing framework of international relations, where states do act on the basis of interests, but also, through the OBOR or Silk Roads, engages in constituting a qualitatively different regional or global relationality. The materialization of the latter is not purely down to the intentions of Chinese leaders; rather its instantiation is dependent on the practices of leaders and populations all along the Silk Roads and the extent to which they mutually constitute shared understandings of their future. The existence of both contestation around these developments, as well as participation in them, are important to the co-emergence of both subjectivity and entanglement along the roads.

${ }^{16}$ See Yan Xuetong, 2011: 142 ) for a discussion of the importance of trust in alliance building. 


\section{References}

Barad, Karen (2007), Meeting the universe halfway: quantum physics and the entanglement of matter and meaning, Durham: Duke University Press.

Bohr, Niels (1958), Atomic Physics and Human Knowledge, New York: Wiley.

Callahan, William A. (20166) 'Çhina’s “Asia Dream”: The Belt Road Initiative and the new Regional Order,' Asia Journal of Comparative Politics, 3: 226-243.

Callahan, William A. (2008), 'Chinese visions of world order: post-hegemonic or a new hegemony?' International Studies Review, 10 (4): 749-761.

Carr, E.H. (2016) The Twenty Year's Crisis: 1919-1939. Palgrave.

Chen, Yurong and Zhong Chao Tang (2014), 'Summary of the International symposium on the Silk Road Economic Belt in the Context of Economic Globalization,' China Institute of International Studies, http://www.ciis.org.cn/english/201403/28/content_6779717.htm (accessed 3 June 2014).

China Daily (2013a), 'XI proposes a 'new Silk road', http://usa.chinadaily.com.cn/china/2013-09/08/content_16952304.htm (accessed 29 June 2014).

China Daily (2013b), 'Xi in call for building of new 'maritime silk road', http://usa.chinadaily.com.cn/china/2013-10/04/content_17008940.htm (accessed 11 August 2014).

China.org (2014), 'China Pledges US \$40 bln for Silk Road Fund', http://www.china.org.cn/wap/2014-11/08/content_34008757.htm (accessed 24 March 2015).

Dobra-Manço, Yasemin (2015) 'China's foreign policy and silk road initiatives spur cultural diplomacy', Silkroutes, http://www.silkroutes.net/OBORChinaSilkRoadRoutesRevival.htm (accessed 7 December 2017).

Edkins, Jenny (2003), 'Security, Cosmology, Copenhagen,' Contemporary Politics 9 (4): 361-370. 
Edwards, Adrian (2016), 'Global Forced Displacement Hits Record High,' UNHRC, 20 June. http://www.unhcr.org/news/latest/2016/6/5763b65a4/global-forced-displacementhits-record-high.html(accessed (20 November 2017).

Fierke, K.M. (2017), Çonsciousness at the Interface: Wendt, Eastern Wisdom and the Ethics of Intra-action.' Critical Review, http://dx.doi.org/10.1080/08913811.2017.1319100

Frankopan, Peter (2015), The silk roads: a new history of the world, London: Bloomsbury.

French, Howard W. (2014) ‘China’s Dangerous Game,' Atlantic Monthly, November. 44-49.

Folger, Tim (2002), 'Does the Universe Exist if We're Not Looking?' Discover 23(6):

Harrell, S. (2013). Cultural Encounters on China's Ethnic Frontiers, Seattle: University of Washington Press.

India's World - China's New Maritime Silk Route (2014), http://www.youtube.com/watch?v=SuCtlyjJMc8

Krishman, Anath (2014) 'China: Billion Dolloar-Fund for Maritime Silk Road,' The Hindu, 20 May.

Lee, Joyman (2011) 'Senakaku/Diaoyu Islands,' History Today, 61, 5, http://www.historytoday.com/joyman-lee/senkakudiaoyu-islands-conflict (accessed 28 February 2017).

Ling, L. H. M. (2014), The Dao of world politics: towards a post-Westphalian, worldist international relations, London, Routledge.

NDRC (2015), 'Vision and Actions on Jointly Building Silk Road Economic Belt and 21st Century Maritime Silk Road, National Development and Reform Commission, People's Republic of China, en.ndrc.gov.cn (accessed 28 February 2017).

NPC (2014), 'Chongjian haishang sichou zhi lu, kaipi yazhou huli gongying xin geju' (Reconstruction of the Maritime Silk Road, opening up a new patter of mutual benefit in Asia)' The National People's Congress of the People's Republic of China, http://www.npc.gov.cn/ (accessed 28 May 2014). 
People’s Daily (2014a), 'Zhongguo "haishang sichou zhi lu” xin tifa yin guoji guanzhu' (China's “Maritime Silk Road” new formulation draws international attention), http://www.people.com.cn/ (accessed 28 May 2014).

People's Daily (2015), 'China Focus: Xi’s 'belt and road' prioritize infrastructure', http://en.people.cn/n/2015/0106/c90883-8831855.html (accessed 24 March 2015).

Phillips, Tom (2017), ‘How Xi Jinping’s Global Ambitions Could Thrive as Trump Turns Inward,' The Guardian, 10 February, https://www.theguardian.com/world/2017/feb/10/how-xi-jinpings-global-ambitions-couldthrive-as-trump-turns-inward (accessed on 17 November 2017)

Pop, Irina Ionela (2016), Strengths and Challenges of China's One Belt, One Road Initiative, Centre for Geopolitics and Realism in Security Studies, 9 February, https://www.academia.edu/31207545/Strengths_and_Challenges_of_Chinas_One belt_One road_Initiative (accessed on 20 November 2017)'.

Pu Zhendong et al (2014), 'State Councilor Urges Cooperation in Silk Road Projects', China Daily, http://www.chinadaily.com.cn/china/2014-04/11/content_17425955.htm (accessed 3 June 2014).

Shambaugh, D. (2013) China Goes Global. New York: Oxford University Press.

Shanghai Daily (2014), 'Fund to Boost China's Maritime Silk Rad Development,' http://shanghaidaily.com/national/Fund-to-boost-Chinas-maritime-Silk-Roaddevelopment/shdaily.shtml (accessed 24 March 2017).

Shi Z. (1993), China's just world: the morality of Chinese foreign policy, Boulder, Colo: Lynn Rienner Publishers.

Sibal, Kanwal (2014), 'China's Maritime "Silk Road” proposals are not as peaceful as they seem', The daily mail, http://www.dailymail.co.uk/indiahome/indianews/article2566881/Chinas-maritime-silk-road-proposals-not-peaceful-seem.html (accessed 28 May 2014).

Tiezzi, Shannon (2014a), 'The Maritime Silk Road Vs. The String of Pearls', The Diplomat, http://thediplomat.com/2014/02/the-maritime-silk-road-vs-the-string-of-pearls/ (accessed 26 June 2014). 
Tiezzi, Shannon (2014b), 'China's “New Silk Road” Vision Revealed', The Diplomat, http://thediplomat.com/2014/05/chinas-new-silk-road-vision-revealed/ (accessed 26 June 2014).

Tsui et al (2017), 'One Belt, One Road: China's Strategy for a New Global Financial Order', Monthly Review Archives, vol. 68, no. 8, 2017 at:

https://archive.monthlyreview.org/index.php/mr/article/view/MR-068-08-2017-01_4 (accessed on 28 February 2017).

Wang Chen (1999), The tao of peace: lessons from ancient China on the dynamics of conflict, translated with an introduction and commentary by Ralph D. Saywer and Mei-chün Lee Sawyer, Boston, Mass; London: Shambhala.

Wang, Robin. (2012). Yinyang: the way of heaven and earth in Chinese thought and culture, Cambridge, United Kingdom: Cambridge University Press.

Wang Yiwei (2017) 'Make One Belt One Road America’s Initiative, Too,' ChinaU.S. Focus, 17 January, https://www.chinausfocus.com/finance-economy/make-one-belt-oneroad-americas-initiative-too (accessed on 8 December 2017).

Wang Zheng (2014) Never Forget National Humiliation: Historical Memory in Chinese Politics and Foreign Relations. Columbia University Press.

Wendt, A. (2015), Quantum mind and social science: unifying physical and social ontology, Cambridge, United Kingdom: Cambridge University Press.

Winter, Tim (2016), 'One Belt, One Road, One Heritage: Cultural Diplomacy and the Silk Road, The Diplomat, http://thediplomat.com/2016/03/one-belt-one-road-one-heritagecultural-diplomacy-and-the-silk-road/ (accessed 28 February 2017).

Xi, Jinping (2014), 'Carry Forward the Five Principles of Peaceful Coexistence to build a better world through win-win cooperation, China.org, http://www.china.org.cn/world/2014-07/07/content_32876905.htm (accessed 23 August 2017).

Xinhua (2015), 'China’s Focus: Xi's 'Belt and Road' Prioritize Infrastructure, 5 January.

Xinhuanet (2014a), 'China Voice: Silk road Spirit will prevail over zero-sum mentality', http://news.xinhuat.net (accessed 29 June 2014). 
Xinhuanet (2014b), 'China Voice: Confrontation, exclusiveness betray Silk Road spirit', http://news.xinhuat.net (accessed 29 June 2014).

Xinhuanet (2014c), 'Maritime Silk Road to bring closer China-Maldives ties: former Maldives senior official', http://news.xinhuat.net (accessed 29 June 2014).

Yale, William (2015), 'China's Maritime Silk Road Gamble', The Diplomat, https://thediplomat.com/2015/04/chinas-maritime-silk-road-gamble/ (accessed 7 December 2017).

Yang Jiechi (2014), 'Jointly Undertake the Great Initiatives with Confidence and Mutual Trust,' speech at 'Reviving the Silk Road: A Dialogue with Asian Leaders,' Boao Forum for Asia Annual Conference, http://pk.chineseembassy.org/eng/zt/Boao2014/t1146601.htm (accessed 3 June 2014).

Yan Xuetong (2011) Ancient Chinese Thought, Modern Chinese Power, edited by Daniel A. Bell and Sun Zhe, Princeton University Press

Zhao Tingyang (2009) A Political World Philosophy in terms of All-under-heaven (Tian-xia), Diogenes, 56, 1. 